\title{
Developing Case Study Learning Models in Writing Report Texts for Students of the English Literature Study Program
}

\author{
$1^{\text {st }}$ Juli Rachmadani Hasibuan ${ }^{1}, 2^{\text {nd }}$ Farida Hanim Saragih ${ }^{2}, 3^{\text {rd }}$ Christine Helena Natalia $^{3}$ \\ \{julirachma@gmail.com ${ }^{1}$ \} \\ English and Literature Department of Faculty of Languages and Arts, Universitas Negeri Medan, \\ Indonesia ${ }^{1,2,3}$
}

\begin{abstract}
This study aims to find out how the case study learning model can improve report text writing skills for English Literature study program students. Sampling 60 students; 30 treatment groups and 30 control groups, the data obtained in this study using the observation guidelines, questionnaires, interview sheets and multiple choice test kits for know the competence of students in writing English. Adopting research development method that refers to the development of model, this development research data is qualitative data and quantitative data. In qualitative data, the data obtained are expressed in sentences and not by numbers. While quantitative data is obtained by giving score. This research also used control group and treatment group in order to examine whether the developed model will affect students writing skills in report text or not. Result shown that the treatment group got higher percentage of improvement compared to the control group in the post test.
\end{abstract}

Keywords: Case Study, Report Text, Learning Model.

\section{Introduction}

In language learning, the four skills namely; writing, listening and speaking have become a benchmark for assessing the success of student achievement. Writing is considered as the most difficult language skill to learn compared to other language skills. In the process of learning, students often complain that writing assignments are very difficult. There are three categories of problems that become a benchmark for difficulty in the writing learning process formulated by Byrne (1988), namely linguistic, cognitive, and content problems.

There are several types of texts (genres) that are taught in the teaching and learning process for the Writing course at the English Literature Study Program, Faculty of Language and Arts, State University of Medan. One of them is commonly called Report Text. Report Text is one types of text that aims to convey information to readers about a subject in the form of people, places or general things based on research results. Based on the results of data analysis on student scores in writing Report Text by the author on students of English Literature study program, it was found that $60 \%$ of English Literature study program students did not meet the Minimum Criteria Completeness (KKM).

Meanwhile, for students who successfully meet the KKM standards, the results of writing Report Texts made by students are still not satisfactory. This raises the assumption or hypothesis that students have not been able to master the learning material. In fact, in the 
practice of learning, mastery of the material is often the main consideration in measuring the level of success of a lecturer in teaching. Deficiencies that occur during the learning process lead to low student achievement.

One of the factors that cause deficiencies in the learning process is the lack of lecturer skills in conducting variations. The application and development of learning models is very important in advancing a particular field. The model is a conceptual structure that has been successfully developed in a field and is now being applied, especially to guide research and thinking in other fields, usually in less developed fields [1].

One of the learning models that are often applied in universities is to use a case study learning model. In the learning process with the Case Study learning model, students and lecturers are jointly required to solve problems contextually using theories that must be mastered by both. This case study learning model is expected the students can gain insight or ideas that are broader and sharper about the things observed in the learning process of writing Report Text. Based on this issue, the author is interested in conducting research on the Development of Case Study Learning Models in Writing Report Texts for students of the English Literature Study Program. Based on the explanation above, it can be formulated two problems as written below:

a. How is the Case Study learning model in writing Report Text for English Literature Study Program students?

b. How the learning model for writing report text can improve the quality of writing skills?

\section{Theory}

\subsection{Model of Learning}

A model of teaching is plan or pattern that we can use to design face to face teaching in classroom or tutorial setting to shape instructional material including books, films, computer mediated programs, and curricula. Each model guided us as we design instruction to help students achieve various objectives. Clearly defined, learning models are conceptual frameworks that contain systematic procedures for organizing learning experiences to achieve certain learning objectives. They serve as a guide for both designers of learning and teachers in the design and implementation of learning activities, respectively.

Learning objectives, interactions, and the nature of the learning environment are used to classify the learning model [2]. 1) A rational, logical theory that was developed by the model's creator or developer; 2) a way of thinking about what will be achieved; and 3) teaching behaviors that are necessary for the model's implementation to be successful; (4) learning environment needed so that the learning objectives can be achieved.his includes presentations, hands-on teaching, concept teaching and cooperative learning as well as problem-based teaching (Case Study) and class discussions. Problem-based learning (Case Study) is one of the most commonly used learning models, and it is the research variable in this study.

\subsection{A Case-Study-Based Learning Framework}

The case study method is one of the learning techniques used in universities (Case Study). This method is thought to help students gain a better understanding of the problems being discussed, as well as develop their analytical skills. When it comes to social sciences there is 
no single definition, but a broad definition divided into four categories. Case studies are a series of intensive, detailed, and in-depth scientific activities that examine a program, event, or activity at the level of an individual, a group, an institution, or organization to gain in-depth knowledge of the event. In general, the target of case study research is the actual thing (Real Life) and unique. It's not something that's past or in the past [3].

It is defined by [4] who define case study as "an in-depth description and examination of an integrated and patterning-based system." A case study identifies parts of the system that are integrated and patterning-based and cannot be separated from one another. Studying a case is intended to reveal the uniqueness or uniqueness of its characteristics [5]. As a result of the case itself, research studies are conducted. Case study research has as its primary goal and focus the case that is the subject of the study. Due to the fact that cases can exist and be found in almost any field, everything related to cases must be investigated in order to explain and understand their existence thoroughly and comprehensively.

\subsection{Writing}

Writing is a linguistic activity that plays an important role in the dynamics of human civilization. Writing as an activity to express ideas, feelings, and opinions for communicate messages from the mind to written form [6]. Writing has two The process step is to display the meaning of the idea and convey it in written form. In expressing ideas, the writer must exploretheir understanding to make the readers interested in their writing and lead the readers to get a wider understandingabout the topic being discussed in their writing. Writing is also a way to communicate the author's ideas or ideas to other writers or readers.

There are several stages in writing, starting from planning, drafting, editing and final draft [7]. The first stage in writing is planning. Planning is a very important stageimportant in writing. In this stage, the writer determines the topic to be studied discussed. The choice of topic is based on the purpose of the writing itself. At stageIn addition, the author expresses opinions on matters relating to writing topics by noting the outlines of their writing.

The second stage is drafting or drafting. At this stage, the writer begins to write. The outline that has been made will be a guideline for writer to write. In the writing process, the writer must develop ideas in paragraphs. Paragraphs that are made mutually continuous with one another.

The third stage is editing. At this stage, the author edits the draft to improve the content and writing style to make it more interesting and easy to read. Writers should also check their writing. When the author edits the draft, the author will make some changes such as adding or reduce one paragraph, change the order of paragraphs, change or eliminate whole sentences or even rewrite sentences with change vocabulary, punctuation and more.

The last stage is the final draft. This stage is very important in writing process. At this stage, the author must rewrite the draft. Writer must pay attention to the details of all words, sentences and paragraphs. This stage will becomes the final stage in writing and refers to the results of writing.

\subsection{Report Text}

Report text is text that presents information about a subject. The social function of Report Text is: describe what is, with reference to various natural phenomena, man-made and social in our environment [8]. While the author [9] said that the purpose of Report Text is to present factual information, usually by classifying things and describing characteristics. Based on the 
statement above, it can be concluded that Report Text's purpose is to classify, describe or presents information about a subject in the form of observations and analysis. In writing Report Text, students must write something that is appropriate for reported by researching and analyzing something.

The generic structure of Report Text includes general classifications and descriptions [8]. General Classification states the classification of general aspects of an object; animal, common, place, plants, etc. which will be discussed in general. While the description, describe things to be discussed in detail; part by part. Gerot and Wignell (1994) give the language features of Report Text:

1. Introducing general statements

Introducing general statements that describe the subject of the textreports, descriptions, and classifications. State the general aspect classification of things researched such as animals, public places, plants, people to be discussed generally.

2. Use of Relational Process

Relational Process is one type of process that is used to express a verb that can describe the state of an object. For example; Plant cells have a cell wall.

3. Using Conditional Logical Connection

Conditional Logical Connection is a word used for connecting two or more sentences so that the compound sentence value produced depends only on the original sentence and on the meaning of the conjunction.

4. Use of Simple Present Tense

The tenses used in the report text are simple present tense, because it tells about a story that is happening right now. Example from simple present tense is: They enjoy the sunset every day.

5. No Temporal Sequence

Temporal Sequence is a word used to connect clause or sentence or to coordinate the words in a clause that same but in Report text, Temporal Sequence is not used. Example Temporal Sequence is first, next, that, last, etc.

\subsection{Learning Case Study Model based on E-learning}

The use of E-learning in a learning environment is one of the methodslearning used through various computer technology tools, networks, computer that is connected to the internet. Based on research results previously proved that learning through E-Learning is possible students to learn through various technological tools, computers, cellphones android wherever they are, each of them without making face-to-face physically to attend lectures [10]. Literature study program UK has a program to optimize the use of network-based technology, along with this lecturers are expected to help the learning process teaching, a combined e-learning system learning is needed with a case study model. In the application, writing learning will be set with a case study model. With this system, it is hoped that students can be more understand and understand the lecture material given by the lecturer, because students can download material in this system and repeat it. 


\section{Method}

This research adopted research development method that refers to the development model [11] consisting of ten steps.

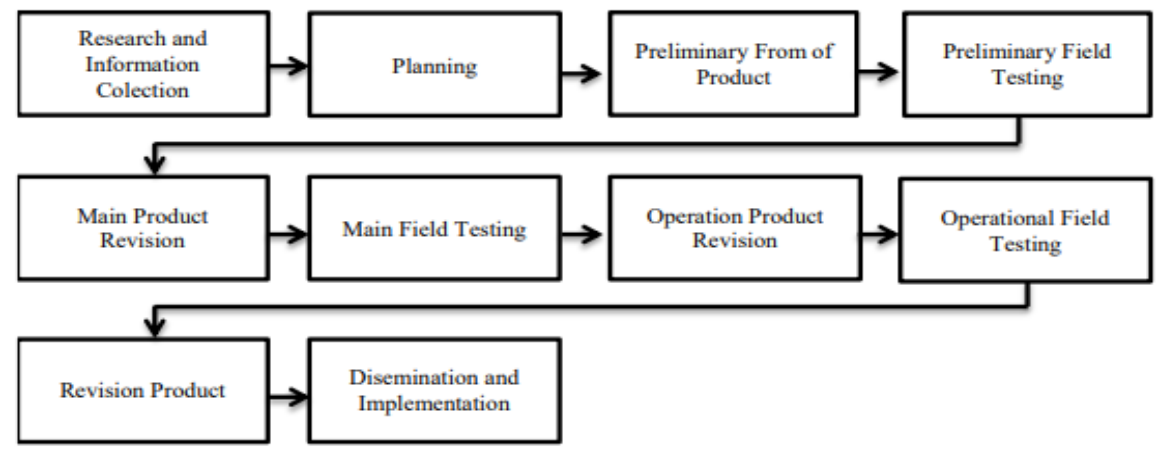

Fig. 1. Development Model Procedure Borg and Gall.

The research was carried out at the Department of English Language and Literature, Faculty of Languages and Arts Medan State University. Time for this research to be carried out in the even semester of 2020-2021.

This study uses a one group pretest-posttest design which combined with a one-shot case study design. In the one-shot case study design, researchers only conduct one-time treatment which is estimated to be already had an effect, then a post-test was held [12]. This design is used to examine the improvement of Report Text writing skills of Study Program students English Literature with Case Study method (Case Study). For more details on the action this design can be seen in the following image.

\begin{tabular}{|l|l|l|}
\hline \multicolumn{1}{|c|}{ Pre-test } & \multicolumn{1}{c|}{ Treatment } & \multicolumn{1}{c|}{ Post-test } \\
\hline O1 & XI & O2 \\
\hline
\end{tabular}

Fig. 2. Case Study method (Case Study).

Information :

O1 : Initial Test Before Treatment

O2 : Final Test After Treatment

$\mathrm{X} 1$ : Treatment Process

The research will use the subject of English Literature Study Program students who are: take the Writing course. Number of subjects involved in the product test scale small as many as 30 students and the number of subjects involved in the trial large-scale product of 50 students. And the number of test subjects effectiveness as much as 60 students (30 treatment groups and 30 control groups). 
The test tools used to obtain data in this study are observation guidelines, questionnaires, interview sheets and multiple choice test kits for know the competence of students in writing English.

Sources of research data and methods used to collect data in this development research are:

a) Data obtained through observations and field notes at the time of analysis requirements, expert validation, during limited product trials as well as extensive product trials.

b) Through a questionnaire as a test instrument for material experts and media experts

c) Data on the results of learning to write using process instruments that have been expert validated. This data was obtained through pretest and post-test. This development research data is qualitative data and data quantitative. Qualitative data, namely the data obtained are expressed in sentences and not by numbers. While quantitative data is obtained by giving score. Then a t-test was carried out for experimental tests by looking at the comparison the average difference between the control class and the experimental class. Statistical calculations The t-test data will be processed using the SPSS 22 program application.

\section{Results and Discussion}

After this research has conducted, it is found that the case study as learning model is more significant in teaching students to write report text rather than the conventional model. The treatment of case study learning models in online basis is applied to the 30 students in the experimental group to see the improvement of their report text writing and the conventional model is applied to the other 30 students in the control group. It is seen based on their post test accumulation result that the experimental group got the more satisfactory score during the process of report text writing.

Table 1. Findings of Pre Test and Post Test.

\begin{tabular}{cccc}
\hline Groups & Pre Test & Treatment & Post Test \\
\hline C & 80 & - & 81.5 \\
\hline E & 80 & Online-Based Case Study Model & 85 \\
\hline
\end{tabular}

Based on the observation conducted with the participants involved, it is gotten that the highest score in pre test was 85 and the lowest score was 75 with the deviation standard gotten was 3.908. After the case study online basis learning model is applied to students in writing report text, it is found that the experimental group member got the higher score in 90 and the lowest score was 80 . The deviation standard gotten was 3.43. There got the mean result of participants in both tests; 81.5 in pre test and 85 in post test.

For the qualitative data gotten based on the questionnaires and interview sheets given, it is found that case study help students gain a better understanding of the problems being discussed, as well as develop their analytical skills. Most of the students responses indicated to how the current case or problems can actually help them to report something in the more detail way so it inspires them more to write the clear description in the report text they are writing.

The data shown that there is the improvement in student's report text writing quality after the treatment of case study model in online basis test is conducted. Before the action was 
carried out, the mean of the pre test given were in the number of 80 , both for the control and experimental group. Then, the researcher gave the one-shot case study learning model as treatment for the experimental group to get the better writing quality of students, especially in writing report text. However, the control group was still taught by conventional method as well.

Result has shown that there were differences between the post testmean gotten in both groups. The control group's mean in post test reached 81.5 , which means it is increased around $1.8 \%$. Meanwhile, the experimental group mean's post test reached into the number of 85 . This indicated the $6.25 \%$ of improvement compared to the pre test given. Considering this, it could be said that the case study learning model is quite effective to be implemented in teaching report text to the English literature students.

Regarding to the first research question, it is found that the case study learning model is a highly adaptable style of teaching that involves problem-based learning and promotes the development of analytical skills. By presenting content in the format of a narrative accompanied by questions and activities that promote group discussion and solving of complex problems, case studies facilitate development of the higher levels of Bloom's taxonomy of cognitive learning; moving beyond recall of knowledge to analysis, evaluation, and application.

Similarly, case studies facilitate interdisciplinary learning and can be used to highlight connections between specific academic topics and real-world societal issues and applications. This has been reported to increase student motivation to participate in class activities, which promotes learning and increases performance on assessments. Moreover, case study research has as its primary goal and focus the case that is the subject of the study. Due to the fact that cases can exist and be found in almost any field so the theme can be various and informative, everything related to cases must be investigated in order to explain and understand their existence thoroughly and comprehensively. The online based case study learning model in improving students' report text writing quality is very effective because through this model, because students are able to discuss and gain more information from the problems or cases being studied then finally develop it into the detail description in report text they made.

Regarding to the second research question, it is shown that there is the improvement on the students' writing skills in writing report text right after the treatment action; case study learning model. Based on the questionnaires as well as the interview sheets results, it is also found that the students are more able to understand how to write report text better after they learnt with online basis case study model. Students opinion were mostly straight into how the cases provided while learning can help them to analyze then describe or report the important object in their report text. Then, this lead them into the better writing quality of report text they made; proved by their result of post-test after one-shot case study treatment is applied.The control group that become the comparison group got the lower improvement rather than the experimental group; the one who was given the online basis case study treatment. Therefore, the case study learning model which is applied in online basis is considered to be the effective model to implement in writing report text by the English literature students. 


\section{Conclusion}

In conclusion, case study learning model is considered to help students gain a better understanding of the problems being discussed, as well as develop their analytical skills. Case study research has as its primary goal and focus the case that is the subject of the study. Due to the fact that cases can exist and be found in almost any field, everything related to cases must be investigated in order to explain and understand their existence thoroughly and comprehensively. Based on the research development conducted, it is found that the case study model significantly improve students' writing quality in report text. Online basis of model also make it more simple as the media to be learnt by the students. This can be seen from the mean score improvement between the two groups involved, both in the pre-test and post-test given. Researchers were also finding that the students become more contributive to write their own report text after the treatment action, as well as it is found on their responses in the questionnaires and interview sheets conducted. Therefore, this case study model is mattered to help students improve English literature's writing skills in writing report text.

\section{References}

[1] Dahar RW. Teori-Teori Belajar. Jakarta: Penerbit Erlangga; 1989.

[2] Rusman. Model-model Pembelajaran. Jakarta: Rajawali Pers; 2013.

[3] Hentz P. Overview of Case Study Research. In Chesnay M. Qualitative Designs and Methods in Nursing. New York: Springer; 2017. 1-10.

[4] Merriam SB, Tisdell EJ. Qualitative research: A guide to design and implementation. San Francisco: John Wiley \& Sons; 2015.

[5] Stake RE. Case studies. In Denzin NK, Lincoln YS. Handbook of qualitative research. Thousand Oaks: Sage Publications Inc; 1994. 236-247.

[6] Fox R. Teacher Talking About Writing. Devon: University of Exeter; 1993.

[7] Harmer J. How To Teach Writing. New York: Grow Hill Press; 2004.

[8] Gerot LA, Wignell P. Making Sense of Functional Grammar. Cammeray NSW: Antipodean Education Enterprises; 1994.

[9] Hyland K. Teaching and Researching Writing. London: Longman Group Ltd; 2002.

[10] Zulaeha I. Innovation Models of Indonesian Learning in Multicultural Society. Procedia - Social and Behavioral Sciences. 2013; 103:506-514.

[11] Gall MD, Gall JP, Borg WR. Educational Research: An Introduction. $8^{\text {th }}$ Edition. New York: Pearson Education; 2007.

[12] Arikunto S. Dasar-dasar Evaluasi Pendidikan. Jakarta: Bumi Aksara; 2009. 